\title{
Gorontalo
}

\author{
Volume 4 - NO. 1 - April 2021 \\ P-ISSN: 2614-2120 E-ISSN: 2614-2104
}

Journal of Government and Political Studies

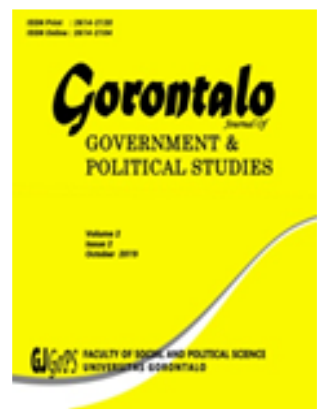

\section{Interaksi Sosial Budaya Masyarakat Desa Banuroja}

\author{
Darwin Une \\ Universitas Negeri Gorontalo \\ Fakultas Ilmu Sosial Universitas Negeri Gorontalo \\ Jl. Jend. Sudirman No.6, Kota Tengah, Kota Gorontalo
}

\begin{abstract}
Received: 24th March 2021 ; Revised: 28 March 2021; Accepted: 29 March 2021
\end{abstract}

\begin{abstract}
This study aims to analyze the socio-cultural interactions in social life. Where ethnicity harmony is very important to be further enhanced, especially in people of different ethnicity or ethnicity, religion and culture. Global issues that arise on the surface of the Indonesian soil cannot come from problems and challenges that touch significantly on the basis of comprehensive peace, security, law and justice. Issues include, among others, the social, cultural and religious fields. Conflicts that occurred in the past few years in several regions in Indonesia have partly accumulated on ethnic SARA issues (ethnicity, religion, race between groups and between ethnicities / tribes). The results of this study indicate that the incidence of conflict in these areas shows us that positive socio-cultural interactions in different Indonesian societies have never been overly established ethnically. However, in some areas or villages there are already more established and maintained positive socio-cultural interactions, for example in Banuroja village, Randangan district, Pohuwato district until now, ethnic harmony between ethnic groups is very well maintained, and positive socio-cultural interactions are always maintained. in those of different ethnicity.
\end{abstract}

Keywords: social interaction; culture; ethnic

\begin{abstract}
Abstrak
Penelitian ini bertujuan untuk menganalisis interaksi sosial budaya dalam kehidupan bermasyarakat. Dimana kerukunan antar-etnis sangat penting untuk lebih ditingkatkan terutama pada masyarakat yang berbeda etnis atau suku, agama dan budaya. Isu-isu global yang muncul kepermukaan bumi Indonesia memang tidak dapat dipisahkan dari maslah-maslah dan tantangan-tatangan yang menyinggung secara signifikan terhadap tuntutan dasar dari perdamaian menyeluruh, keamanan, hukum serta keadilan. Isu-isu ini antara lain mencakup bidang sosial, budaya dan agama. Konflik yang terjadi pada beberapa tahun lalu di beberapa wilayah di Indonesia sebagian berkaumulasi pada masalah SARA (suku, agama, ras antar golongan dan antar etnis/suku). Hasil penelitian ini menunjukkan bahwa, terjadinya konflik di daerahdaerah tersebut secara inplisit menunjukkan kepada kita bahwa ternyata interaksi sosial budaya yang sifatnya positif pada masyarakat Indonesia yang berbeda etnis belum terlalu mapan betul. Meski demikian, di beberapa wilayah atau desa sudah ada yang lebih mapan dan terpelihara interaksi sosial budaya yang sangat positif, contohnya di desa Banuroja Kecamatan Randangan Kabupaten Pohuwato sampai saat ini kerukunan antar etnis sangat terpelihara baik, serta interaksi sosial budaya yang sifatnya positif selalu terjaga pada mereka yang berbeda etnis.
\end{abstract}

Kata Kunci: interaksi sosial; budaya; etnis 


\section{PENDAHULUAN}

Manusia dalam statusnya merupakan makhluk individu sekaligus tidak lepas dari manusia sebagat makhluk sosial, yang tentu selalu tumbuh dan berkembang karena dipengaruhi dan mendapat bantuan dari manusia lain. Artinya manusia tidak dapat hidup dan berkembang apabila tidak memperoleh pertolongan dari orang lain. Oleh itu setiap individu sangat berarti kehidupannya kalau berkecimpun dengan kelompok masyarakat serta selalu berinteraksi satu sama lainnya. Menurut istilah Soekmono (1983 : 10) manusia dikatakan sebagai "Zoon politikon" artinya manusia yang hidup berkelompok. Ini berarti walaupun manusia sebagai makhluk individu seperti disebutkan diatas, namun bagaimanapun juga ia tidak lepas dari individu yang lain dalam hubungan dengan statusnya sebagai manusia bernasyarakat.

Ahli sosiologi memandang kehidupan masyarakat dari dua segi yakni segi statis dan segi dinamis. Segi statis manusia tidak memperlihatkan aktifitas atupun kegiatan bahkan untuk mencari hubungan dengan orang lainpun jauh dari statusnya sebagai makhluk sosial. Dari segi dinamis manusia selalu berupaya mendapatkan perubahan dan perkenbangan sejalan dengan kehidupan sebagai makhluk Tuhan yang diberi kedudukan diimuka bumi ini.

Perubahan dan perkembangan masyarakat yang mewujudkan segi dinamikanya karena selalu mengadakan hubungan dengan yang lain atau selalu berinteraksi antar sesama. Dan hal ini memang perlu dalam krangka kehidupan masyarakat, baik itu masyarakat diperkotaan maupun masyarakat dipedesaan tanpa melihat atau memandang apakah masyarakat itu satu suku atupun berbeda suku. Demikian manusia dalam statusnya sebagai mahkluk sosial dijadikan oleh sang pencipta secara horizontal hidup berdampingan dengan makhluk sesamanya dan menyadari bahwa kehidupan ini tidak lepas dari segala bentuk kekurangan dan kelebihan. Dalam dinamika kehidupan sosial kadangkala terdapat hubungan kekerabatan yang erat, namun tidak lepas pula dari suatu hubungan yang renggang antara sesama. Hal ini kadangkala pula disebabkan karena terdapatnya perbedaan suku (etnis) pada satu desa tertentu sehingga berakibat pula pada kurangnya interaksi sosial yang terbina dalam kehidupan sehari-hari. Salah satu indikator yang tidak dapat dibantah adalah munculnya kesenjangan sosial yang dari hari kehari semakin melebar dan bila tidak cepat diantisipasi maka akan merupakan ancaman bagi pembangunan pada satu sisi dan persatuan dan kesatuan bangsa pada sisi lainnya yang kedua-duanya sama-sana diusahakan.

Terjadinya konflik di daerah-daerah tersebut secara inplisit menunjukkan kepada publik bahwa ternyata interaksi sosial budaya masyarakat Indonesia yang berbeda-beda etnis belum mapan betul. Pernyataan bahwa daerah yang berbeda-beda etnis kadangkala timbul kerawanan sosial, maka masalah yang timbul adalah apakah hal ini berlaku juga didaerah-daerah lain misalnya didaerah Kabupaten Gorontalo khususnya Desa Banuroja Kecamatan Randangan Kabupaten Pohuwato dewasa ini hidup masyarakat yang berbeda etnis dan konon masyarakatnya hidup damai tidak pernah ada konflik diantara mereka. Asrul Muslim dalam penelitiannya menjelaskan bahwa beberapa permasalahan yang dapat menghasilkan bentuk interaksi sosial yang sifatnya asosiatif adalah, etnosentrisme, misunderstanding in value, streotip, dan prasangka (Muslim, 2013). 
Yoseph Taun menjelaskan dalam penelitiannya bahwa dalam masyarakat yang multietnik, pola dan model pergaulan yang etnosentrik dapat berakibat kontraproduktif. Usaha bisnis yang maju pesat dan dikuasai oleh satu kelompok etnis sama seperti menyimpan bom waktu yang pada saat tertentu akan menimbulkan ledakan sosial. Sosialisasi kesadaran multietnik dapat dilaksanakan melalui konsep proses sosial, yaitu suatu cara berhubungan antarindividu atau antarkelompok atau individu dengan kelompok yang menimbulkan bentuk hubungan tertentu. Dari hubungan ini diharapkan mereka semakin saling mengenal, semakin akrab, lebih mudah bergaul, lebih percaya pada pihak lain, dan akhirnya dapat bekerjasama dan bersinergi. Kesemuanya ini dapat dipahami sebagai bagian dari peradaban manusia (Taum, 2006).

Sejalan dengan hal tersebut Alo Liliweri Prasangka dan Konflik; Komunikasi Lintas Budaya Masyarakat Multikultur, menjelaskan bahwa konflik menjadi semakin mungkin terjadi pada masyarakat. Hal ini dengan melihat bahwa masyakarat menjadi semakin rentan ketika mencul ketidaksepakatan dalam prosedur dalam mencapai tujuan. Peneltian terkait konflik sosial juga dilakukan oleh Safitri yang menggambil kajian budaya Suku Makassar. Interaksi sosial masyarakat Sulawesi Selatan terdiri dari suku Bugis, Makassar, Mandar, dan Toraja. Keempat suku bangsa tersebut memiliki ciri budaya yang telah menjadi adat istiadat dan filosofi kehidupannya karena memiliki unsur nilai normatif yang dapat mengikat anggotanya. Hasil penelitian menunjukkan bahwa etnis Sulawesi Selatan telah membangun interaksi sosial yang didasarkan pada budaya Siri 'Na Pacce dan Sipakatau yang menjadi tumpuan utama dalam membangun komunikasi yang positif antar sesama. Budaya tersebut harus diterapkan dan dipertahankan dengan baik dalam membangun interaksi sosial (Safitri 2020).

Dari pengamatan yang telah dilakukan dapat masyarakat sangat rentan terhadap konflik sosial dan budaya. Kemajemukan bangsa Indonesia selain menjadi milik juga menjadi bumerang bagi persatuan suatu bangsa. Konflik yang muncul tidak akan terselesaikan jika dibiarkan begitu saja. Perselisihan tersebut dapat diatasi dan dihindari jika masyarakat dapat membangun interaksi sosial yang positif antar sesama. Oleh karena itu dalam menghadapi konflik perlu disadari bahwa suatu suku bangsa bukanlah suatu kelompok sosial yang harus diperhatikan, akan tetapi suatu kearifan lokal yang tersimpan dalam suatu budaya suku bangsa.

Sebagai hipotesa pertama untuk menjawab masalah di atas adalah nampaknya bahwa kondisi sosial masyarakat desa Banuroja Kecamatan Randangan yang majemuk itu meskipun memiliki latar belakang perbedaan suku, agama, adat-istiadat dan bahasa, namun mereka mampu menciptakan suasana yang harmonis, aman dan tertib. Proses interaksi sosial budaya masyarakat di desa Banuroja yang berbeda etnis memang lebih mantap dibanding dengan daerah-daerah lain. Hal inilah yang selanjutnya akan menjadi bahan kajian dalam penelitian ini.

\section{METODE PENELITIAN.}


Memperhatikan permasalahan penelitian sebagaimana yang telah diuraikan pada bab terdahulu, maka secara implisit tersirat bahwa variabel penelitian ini bersifat tunggal. Adapun variabel penelitian ini adalah interaksi sosial budaya masyarakat Desa Banuroja yang berbeda etnis, dengan indikator-indikator sebagai berikut: Adanya penyesuaian diri pada kaedah-kaedah yang berlaku; Kemauan melakukan hubungan kerja sama dengan warga masyarakat yang berbeda etnis; Kemauan menerima unsur-unsur inovatif yang dimunculkan oleh etnis lain; Kesediaan melangsungkan hubungan kekerabatan yang lebih erat dengan lain etnis; Kepedulian terhadap kehidupan lingkungan budaya sekitar. Objek atau lokasi Penelitian adalah Desa Banuroja Kecamatan Randangan dan subjek penelitian adalah masyarakat yang berbeda etnis. Sedangkan teknik penelitian menggunakan teknik purposive sampling. Jumlah anggota sampel akan ditentukan menurut kehendak peneliti dan diambil dari wakil-wakil etnis yang jumlahnya secara proporsional.

\section{HASIL PENELITIAN DAN PEMBAHASAN.}

Upaya pemerintah untuk menbangun dan mengembangkan desa/kota serta menempatkan masyarakat sebagai makhluk Tuhan yang hidup secara layak dan berdampingan dengan masyarakat lainnya dimuka bumi ini adalah agar dalam hidup ini merasa berkecukupan walau masyarakat sadar bahwa tidak diberi bantuan oleh orang lain. Karena itu perbedaan etnis atau suku bukan menjadi ajang perpecahan pada suatu desa dimana desa itu hidup suatu manyarakat yang berbeda suku, agama, bahasa, budaya dan adat-istiadat. Seperti desa Banuroja menjadi desa tempat pemukiman masyarakat transmigrasi yang berasal dari berbagai daerah yang berbeda etnis. Namun paerbedaan etnis bukan merupakan jurang pemisah antara satu suku dengan suku yang lain karena disebabkan oleh perbedaan latar belakang kehidupan dan strata sosial dari masing daerah.

Tentu upaya pemerintah untuk menjadikan desa Banuroja ini menjadi desa yang dihuni oleh masyarakat yang tidak membeda-bedakan etnis satu dengan etnis lainnya sangat disambut positif oleh masyakat. Sedikitnya ada 3 hal yang menjadi tujuan pemerintah untuk mengembangkan suatu desa yakni (1) menempatkan warga desa dalam kedudukan yang sebenarnya sebagai warga desa dalam wadah Indonesia, arttinya tidak ada perbedaan status antara penduduk desa dengan penduduk kota seperti pada zaman Kolonial. (2) mengusahakan agar corak kehidupan dan penghidupan warga desa dapat ditngkatkan atas dasar alam pikiran yang logis, fragmatis dan rasional. (3) mengusahakan agar warga desa dapat lebih bersitat kreatif dinamis dan fleksibel dalam menghadapi kesulitan-kesulitan yang dijumpai, sehingga dapat lebih meningkatkan semangat membangun serta memperbaiki taraf hidup mereka" (Bintarto $1983: 11$ ).

Terkait dengan persoalan masyarakat sebagai satu komunitas yang hidup secara heterogen, maka lambat atau cepat selalu menimbulkan gejala sosial, ekonomi termasuk politik. Gejala sosisl ekonomi yang timbul diakibatkan oleh karena mungkin timbulnya persaingan di dalan kehidupan untuk mempertahankan status sosial, bahkan kadangkala hanya karena kesalahpahaman dalan bertindak diantara sesama dalam lingkungan yang berdampingan atau bertetangga sehingga berakibat timbulnya konflit. Inilah, suatu dinamika kehidupan masyarakat yang dinilai termasuk juga sebagai 
wujud dari pada interak sisosial seperti di desa Banuroja. Terdapat beberapa faktor yang mendorong masyarakat Banuroja shingga tetap menjaga interaksi sosial budaya yang sifatnya positif.

Faktor yang pertama adalah kemauan masyarakat untuk menyesuaikan diri dengan kaidah-kaidah yang berlaku ditempat pemukiman yang baru setelah meninggalkan daerah pemukiman mereka yang sebelumnya. Dengan berbekal adat kebiasaan lama masyarakat pendatang memiliki sifat terbuka dan menghargai adat kebiasaan masyarakat setempat, sehingga rasa tertekan /asing tidak menjadi beban masyarakat pendatang.

Faktor kedua yang memperkuat proses interaksi sosial masyarakat desa Banuroja yang berbeda etnis adalah adanya kemauan warga masyarakat untuk melakukan hubungan kerja sama dengan warga masyarakat lainnya, tanpa membeda-bedakan suku, agama dan ras. Dalam kenyataannya masyarakat di desa Banuroja memandang bahwa kerja sama antar sesama warga adalah sangat penting, karena disadari bahwa ditempat yang mereka huni tersebut mereka memerlukan bantuan orang lain. Tidak ada manusia yang dapat hidup sendiri, tanpa pertolongan orang lain.

Selanjutnya faktor ketiga yang memperkuat interaksi sosial budaya masyarakat desa Banuroja adalah adanya kemampuan masyarakat untuk menerima pengaruh unsur-unsur baru yang inovatif. Dengan perkembangan $1 \mathrm{mu}$ pengetahuan dan teknologi yang semakin pesat dewasa ini, telah membuka peluang bagi daerah-daerah yang terisolasi untuk maju dan mengejar ketinggalannya.

Faktor yang keempat, yang mondorong kuatnya interaksi sosial budaya masyaralat desa Banuroja Kecamatan Randangan adalah ketersediaan untuk melangsungkan hubungan kekerabatan yang lebih erat dengan etnis lain. Hubungan kekerabatan yang lebih erat dan akrab sudah tentunya harus melalui jalur perkawinan. Maka bagi masyarakat desa Banuroja melangsungkan hubungan perkawinan meskipun dengan keluarga yang berasal dari suku lain tidak menjadi masalah. Dalam arti masyarakat tidak mempermasalahkan perkawinan antar suku. Bagi mereka hal yang demikian adalah merupakan masalah yang biasa saja karena tidak tercela dari segi hukum dan norma yang berlaku dalam masyarakat.

Hasil temuan penelitian yang dibahas berdasarkan rumusan masalah yakni bagaimana hubungan kerja sama antar masyarakat yang berbeda etnis. Lalu bagaimana kekerabatan dan kehidupan beragama terutama toleransi antar agama masyarakat desa Banuroja yang berbeda etnis. Selanjutnya apakah terdapat kesenjangan atau konflik sosial dalam kehidupan masyarakat serta adakah kemauan masyarakat desa Banuroja yang berbeda etnis menerima inovatif yang dimunculkan oleh etnis lain, dan terakhir bagaimana interaksi sosial budaya masyarakat desa Banuroja Kecamatan Randangan yang berbeda etnis. Uraiannya sebagai berikut:

\section{Hubungan Kerjasama Antar Etnis Masyarakt Desa Banuroja.}

Berbeda etnis yang hidup di desa Banuroja ini menurut hasil wawancara dengan kepala desa selalu menjalin kersama. Menurut Kepala Desa Banuroja, jalinan kerjasama antar suku atau etnis masyarakat taransmigrasi ini sudah berlangsung lama sejak mereka bermukim di desa Banuroja ini, sebab kalau tidak demikian hidup di suatu daerah yang sangat jauh dari keluarga akrab 
yang ditinggalkan di daerah asal tidak lagi memperhatikan bahkan sudah tidak lagi membantu apa yang menjadi kekurangan dalam pemenuhan kebutuhan sehari-hari. Makanya mau tidak mau harus membangun kedekatan secara emosional dengan kerabat tetangga yang berbeda suku. Paling tidak selalu menjalin interaktif sosial positif antar tetanngga dan selalu menghindari interaktif secara negatif untuk menghindari terjadinya konflik (Wawancara dengan kepala desa 2020).

Masyarakat Banuroja yang berbeda etnis sangat tinggi rasa toleransi satu sama lainnya serta selalu saling interaktif dalam setiap kegiatan-kegiatan yang sifatnya sosial ataupun sifatnya tradisi dan budaya setiap etnis. Tradisi dan budaya semua etnis desa Banuroja terus menerus dijalani agar hal ini tetap terjalin hidup rukun damai antar etnis lebih-lebih antar beragama (wawancara dengan I Made Suardana 2020).

Lebih lanjut dalam wancara dengan I Made mengatakan bahwa : Hal yang sangat menonjol dalam kehidupan antar etnik sampai bisa terbangun interaksi sosial budaya Banuroja ini adalah misalkan ketika saat peringatan hari-hari besar Islam seperti Maulid, peringatan Isra' Mi'raj bahkan sampai perayaan hari raya idul fitrih (hari raya umat Islam) warga dari semua etnik yang berbeda agama baik itu yang bergama Hindu, Nasrani maupun yang punya keyakinan lainnya, selalu berbondong-bondong meramaikan suasana sekaligus menyertakan aneka macam makanan untuk diserahkan kepada umat muslim yang sedang merayakan lebaran idul fitri tersebut.

Lebih lanjut I Made menjelaskan bahwa, ketika tiba saatnya giliran perayaan Natal bagi agama Nasrani, warga yang bergama Islam dan Hindu ramai-ramai meneyerahkan hasil bumi seperti jagung, jeruk, buah-buahan dan lain sebagainya. Demikian pula saat umat Hindu merayakan hari Nyepi atau hari raya Galungan umat Islam dan umat Nasrani memberikan apa yang menjadi kebutuhan umat Hindu ketika dalam nuangsa perayaan Hari Raya Nyepi, bahkan toleransinya umat Islam terhadap umat Hindu disaat mereka menjalankan Nyepi tidak ada satu mesjidpun yang mengumandangkan azan di waktu-waktu ibadah sholat. Ini tandanya bahwa umat Islam di Banuroja sangat menghargai umat Hindu dalam menjalankan Nyepi (wawancara dengan tokoh agama 2020).

Dari pengamatan tersebut dapat kita analisis bahwa terjalin kerukunan masyarakat yang baik antar umat beragama di Desa Banuroja. Hal ini tercermin dari bentuk kerjasama dan penghargaan terhadap hari-hari besar keagamaan. Hal ini menjadi penegasan bahwa perbedaan etnis dan agama tak membuat warga Banuroja terpecah belah bahkan justru semakin mempererat tali silaturrahmi dalam setiap perayaan.

\section{Kekarabatan dan Toleransi Beragama Antar Etnis}

Untuk mengendlikan suasana agar selalu terjaga kekerabatan dan persaudaraan antar etnis menurut I. Made Suardana (Kepala Desa Banuroja) ada satu orang tokoh agama yang dituakan yaitu KH Abdul Ghofur Nawai. Beliau adalah salah seorang tokoh agsama sekaligus pendiri Posantren Salafiah Syafiiyah yang sangat dihargai dan dihormati karena selalu dapat mengendalikan suasana kehidupan Bergama di Desa Banuroja.

Ketika peristiwa tragedi bom Bali yang lalu sehingga membuat perselisihan dan ketersinggungan antar warga yang beragama Hindu dengan warga yang 
beragama Islam, maka KH Abdul Ghofur Nawai inilah yang berusaha meyakinkan umat Hindu agar tetap menjaga toleransi keberagamaan dengan merangkul para tokoh lain di Desa Banuroja hingga akhirnya tidak terjadi pertikaian yang sangat merugikan semua pihak. Prinsip yang selalu dipegang teguh oleh masyarakat adalah pinsip yang bermakna saling bantu dengan suasana kekeluargaan membingkai masyarakat desa Banuroja yang hidup rukun dalam keberagaman agama dan etnis.

Ketika masuk ke Desa Banuroja nampak gapura ornament khas Bali setinggi tiga meter menyapa kedatangan para tamu yang datang seolah-olah tamu memasuki perkampungan umat Hindu. Sebab pada sisi kiri dan kanan gapura tertulis ucapan selamat datang di Desa Wisata Banuroja Kecamatan Randangan Kabupaten Pohuwato Propinsi Gorontalo. Sekitar kurang lebih 150 meter dari gapura tampak berjejer rapi dan teratur dipinggir jalan pemukiman rumah-rumah penduduk. Di depan setiap rumah terdapat pura dan ini menunjukkan nuansa Hindu Bali terasa sangat kental. Akan tetapi semakin kita menyusuri jalan utama lebih kurang 400 meter kemudian tampak papan nama Pondok Posantren Salafiah Sayafi'iyah cukup mencolok. Demikian pula gapura pintu gerbang masuk ke SMK Salafiah Safi'iyah sangat menarik seperti yang lainnya misalnya disebelahnya tepatnya di atas bukit sisi kiri jalan utama menjulang pura yang menjadi tempat ibadah umat Hindu.

Tentu bukan saja tempat ibadah umat muslim yakni mesjid yang berdekatan dengan pura tempat ibadah umat Hindu, melainkan kurang lebih 100 meter di lokasi pura terdapat dua buah Gereja, yaitu Gereja Protestan Indonesia Gorontalo (GPIG) Imanuel, dan yang kedua Gereja Pantekosta Banuroja. Kedua Gereja ini berdekatan kurang lebih 50 meter. Menariknya, meski lokasi tempat ibadah berdekatan dan berdampingan, namun tidak pernah ada gesekan dan konflik yang mengatasnamakan agama. Ini menunjukkan bahwa warga Desa Banurajo yang berbeda etnis dan beda agama hidup rukun dan damai dalam bingkai kekeluargaan.

Dari kondisi nyata yang dicerminkan oleh masyarakat Desa Benuroja di lapangan, menekankan bahwa konflik etnis dan agama sangat dapat diminimalkan dengan menanamkan rasa toleransi. Masyarakat yang berbeda etnis dan agama dapat hidup berdampingan menunjukkan pola kehidupan yang aman dan selalu bekerja sama.

\section{Interaksi Sosial Budaya Masyarakat Desa Banuroja yang Berbeda Etnis.}

Membangun interaksi sosial budaya dikalangan masyarakat, kadang kala dianggap sulit. Karena ketika suatu wilayah tertentu dihuni oleh masyarakat yang berbeda-beda etnis/suku dan belum saling kenal mengenal, maka jelas komunikasi antar orang yang berbeda suku itu pasti tidak berjalan baik. Lambat ataupun tidak hal ini tetap dialami oleh masyarakat itu sendiri. Contoh yang bisa dilihat adalah ketika di suatu desa dan disitu terbagun perumahan lalu perumahan itu sudah dihuni oleh masyarakat yang kadangkala dalam proses yang lama baru dapat dikenal dari mana asal daerahnya. Ini karena satu rumah dengan rumah yang lain sangat jarang membangun komunikasi yang bisa berwujud interksi sosial. Pada akhirnya untuk memenuhi kebutuhan kalau misalkan satu rumah mengalami kekurangan sulit terpenuhi karena masingmasing hidup secara individual dalam arti tidak saling kenal mengenal. 
Beda halnya dengan masyarakat Banuroja yang nota benenya adalah masyarakat transmigrasi dari berbagai daerah di Indonesia, berbeda-beda etnis dan agama namun komunikasi terjalin baik dalam wujud interaksi sosial budaya. Meski awal-awal kedatangan mereka ini ada yang bertahan hidup di pemukiman daerah taransmigrasi, tetapi ada pula yang tidak bertahan dan akhirnya memilih untuk pulang ke daearah asal mereka. Yang bertahan tidak pulang inilah mereka hidup rukun, damai sejahtera bahkan banyak yang sudah berhasil. Kebanyakan dari mereka adalah yang berasal dari Bali, karena masyarakat Bali memang terkenal dengan etos kerja tinggi baik laki-laki maupun perempuan. Seperti yang diutarakan oleh kepala desa I.Made dalam wawancara bahwa, masyarakat Hindu Bali itu tidak ada dalam kamus kalau memilih-milih pekerjaan baik perempuan maupun laki-laki dalam mencari kebutuhan sepanjang itu pekerjaan halal. Dan ini bukan saja nanti di daerah transmigrasi atau daerah orang lain etos kerja orang Bali ini memang tinggi dan harus hidup membanting tulang. Di daerah asal pun kehidupan orang Bali sudah terbiasa dengan pekerjaan menantang. Hanya masalahnya di daerah asal sudah sulit cari pekerjaan sementara lahan-lahan hunian sudah tidak memungkinkan untuk dihuni oleh karena penduduk semakin padat maka mau tidak penduduk lain harus dipindahkan (transmigrasi) ke daerah lain antara lain seperti di desa sekarang ini Banuroja Kecamatan Randangan Kabupaten Pohuwato (wawancara 2020).

Dari hasil penelitian di lapangan, terlihat bahwa interaksi positif dari masyarakat di Desa Banuroja. Interaksi ini melibatkan rumput masyakarat yang berbeda secara etnis dan agama. Dimana adanya penghargaan yang tinggi terhadap kepercayaan tiap warga menjadi faktor utama. Tidak adanya dominasi dan marginalisasi menjadikan tiap warga masyarakat mampu menjalankan ibadah dan kepercayaannya dengan baik.

Di samping itu, kompleksitas masyarakat Desa Benuroja juga ditambah dengan adanya warga pendatang melalui program transmigrasi. Akan tetapi hal ini tidak menjadi mesalah bagi warga lokal. Pada kenyataanya warga lokal dan pendatang mampu bekerja secara bersama-sama terutama dalam sektor ekonomi. Yang terjadi justru warga pendatang menjadi motivasi dengan etos kerja yang dimiliki bagi warga lokal Desa Benuroja.

\section{PENUTUP}

Masyarakat di Desa Banuroja Kecamatan Randangan merupakan suatu kesatuan masyarakat yang majemuk, terdiri dari berbagai macan suku bangsa, agama, adat-istiadat dan kebudayaan. Meskipun bersifat majemuk, namun warga masyarakat tetap hidup berdampingan dengan suasana yang rukun dan tentram. Bahwa masyarakat di desa Banuroja yang rata-rata adalah para transmigran, ternyata telah mampu menyesuaikan diri dengan kaidah maupun adat istiadat yang berlaku di tempat pemukiman yang baru. Dalan konteks hubungan horisontal, masyarakat di desa Banuroja dapat menciptakan suasana yang harmonis melalui jalinan hubungan kerja sama yang erat dengan warga masyarakat lain yang berbeda. Demikian pula halnya dengan hubungan kekerabatan. Ternyata telah terjalin ikatan kekerabatan yang lebih akrab antara warga masyarakat melalui proses parkawinan antar Suku.

Berdasarkan kesimpulan di atas tentang Proses Interaksi Sosial Budaya masyarakat Desa Banuroja Kecamatan Randangan Kabupaten Pohuwato dalam 
menciptakan suasana yang harmonis, aman dan tertib, dapat direkomondasikan hal-hal sebagai berikut:

1. Suasana yang harmonis, damai dan tentram dalan kehidupan masyarakat desa Banuroja Kecamatan Randangan, hendaklah tetap dijaga dan dipelihara demi keutuhan persatuan dan kemajuan bangsa Indonesia. Masyarakat di desa Banuroja diharapkan menghindari terjadinya bentrokan dan konflik sosial dengan menghilangkan sifat fanatisme suku dan fatanisme agama yang berlebih-lebihan.

2. Kepada para penentu kebijakan diharapkan untuk terus menerus menyalurkan bantuan dan perhatiannyaa agar taraf hidup dan tingkat kesejahteraan masyarakat desa Banuroja dapat lebih meningkat. Terlebih dalam suasana sekarang ini yang sedang merebahnya Pandemi Covid-19 yang cukup dirasakan akibatnya oleh masyarakat luas, maka bantuan pemerintah baik pusat maupun daerah sangat diharapkan oleh masyarakat di pedesaan pada umumnya dan kususnya desa Banuroja.

\section{DAFTAR PUSTAKA}

Ahmadi A. 1986 Antropologi Budaya, Surabaya; Pelangi

Bintoro R. 1983 Interaksi Desa Kota dan Permasalahannya. Ghalia Indonesia

Cholil Mansyur. 1987 Sosiologi Masyarakat Kota dan Desa, Surabaya Indonesia, Usaha Nasional.

Harsoyo. 1986 Pengantar Antropologi, Bandung ; Bina Cipta.

Hemafitria, H. (2019). Konflik Antar Etnis Melalui Penguatan Wawasan Multikultural. Jurnal Pendidikan Kewarganegaraan, 3(1), 1-11.

Ihroni. T.O. 1980 Pokok-Pokok Antropologi Budaya, Jakarta Gramedia.

Koentjaraningrat. 1977 Metode-Metode Penelitian Masyarakat.

.------------- 1986 Pengantar Ilmu Antropologi, Jakarta Aksara Baru. Gramedia.

Liliweri, A. (2005). Prasangka dan Konflik; Komunikasi Lintas Budaya Masyarakat Multikultur. LKiS Pelangi Aksara.

Muslim, A. (2013). Interaksi sosial dalam masyarakat multietnis. Jurnal Diskursus Islam, 1(3), 483-494.

Pelly dan Mananti. 1994 Teori-Teori Sosial Budaya. Depdikbud Jakarta

Soekmono R. 1983 Pengantar Sejarah Kebudayaan Jilid I. Jakarta; Yayasan Kanisius.

Taum, Y. Y. (2006). Masalah-masalah Sosial dalam Masyarakat Multietnik. Makalah dibawakan dalam Focus Group Discussion IFGD)" 1dentifikasi Isuisu Strategis yang. 